\title{
Ratio Analysis of Tesco Plc Financial Performance between 2010 and 2014 in Comparison to Both Sainsbury and Morrisons
}

\author{
Adejumo Wahab Adewuyi \\ The Oke Ogun Polytechnic, Saki, Nigeria \\ Email:waa14adejumo@gmail.com
}

Received 5 May 2016; accepted 26 July 2016; published 29 July 2016

Copyright (C) 2016 by author and Scientific Research Publishing Inc.

This work is licensed under the Creative Commons Attribution International License (CC BY).

http://creativecommons.org/licenses/by/4.0/

\section{(c) (i) Open Access}

\begin{abstract}
Ratio analysis is a method of assessing and comparing the performance of a company in a particular year to previous years' performance and possibly with other companies in the same industry. This paper aims at analyzing the financial performance of Tesco Plc between 2010 and 2014 and compares it with the performance of both Morrisons and Sainsbury. The paper intends to make use of financial statements of Tesco, Sainsbury and Morrisons from 2010 to 2014. From the data analysis, it is discovered that from 2010, the financial performance of Tesco Plc is not improving and the shareholders' wealth has been decreasing. Not only that, the Gross Profit, Return on Capital Employed, Dividend payment, Share prices, etc. have been reducing from year to year. The consequence of this is that Tesco Plc may run into loss in the nearest future if not in 2015. The paper recommends that Tesco needs to adjust his business activities so as to improve its performance.
\end{abstract}

\section{Keywords}

Profitability Ratio, Liquidity Ratio, Efficiency Ratio, Tesco Plc

\section{Introduction}

First of all, ratio analysis is a method of assessing and comparing the performance of a company in a particular 
year to previous years' performance and possibly comparing the same performance with other companies in the same industry. As it is widely accepted that Retail superstore grocery market of UK is a highly competitive market and there is a need to carefully analyze the strengths and weaknesses of each company to promptly identify and exploit potential opportunities in the market.

\section{Tesco Plc}

Tesco Plc is a global leading retailer. Retailing is a highly competitive industry characterized by low profit margins, brand recognition, inventory management and economies of scale. Tesco mostly focuses on food products. Tesco has a strong grocery brand and high customer loyalty in the UK and has been using their brand power to expand their business into the banking sector with promising results. Aggressive growth has been pursued internationally with generally good results from Asia with the focus shifting to the fragmented but competitive Chinese market. Tesco is also trying to gain a foothold in the competitive western US grocery market by developing distribution networks and scale and expensively undercutting its competitors.

Tesco Plc was the leading retailer in the United Kingdom going by volume of sales, number of sales outlets and other similar factors. However, this ratio analyses carried out revealed some of outstanding performance of Tesco Plc at 2010 as well as the areas of poor management performance. In one word, from 2010, the financial performance of Tesco Plc is not improving. The Shareholders' wealth has been decreasing. Not only that, the Gross Profit, Return on Capital Employed, dividend payment, share prices, etc. have been reducing from year to year. The consequence of this is that Tesco Plc may run into loss in the nearest future if not in 2015.

\section{Research Methodology}

The data for this paper will be the financial statements of Tesco, Sainsbury and Morrisons between 2010 and 2014 and these will be downloaded from the respective company's website. The data analysis will be followed with the use of graphs and simple percentages.

\section{Data Analysis}

The common ratios are widely accepted as a method of comparing performance of retail outlets and these include but not limited to the following:

\subsection{Profitability Ratio}

The term "profitability” means the profit earning capacity of any business activity. The Profitability Ratio is used to measure the overall efficiency or performance of a business. This ratio indicates the extent a business is making profits.

It has been established that profitability ratios are a class of financial metrics that are used to assess a business's ability to generate earnings as compared to its expenses and other relevant costs incurred during a specific period of time. For most of these ratios, having a higher value relative to a competitor's ratio or the same ratio from a previous period is indicative that the company is doing well.

Profitability Ratio consists of the following:

1) Return on Capital Employed

ROCE is referred to as the "primary ratio". It measures the relationship between profit and capital employed. In short, it indicates the returns the company has made on the resources made available to the business before making any distribution of those returns. This ratio is very significant because it highlights the success of the business from the shareholder's perspective and determines the efficient handling of owner's investment. The higher the ratio is, the better the business is. $10 \%$ to $20 \%$ is ideal ratio for a performing company.

$$
\text { ROCE }=\frac{\text { Operating Profit }(\text { Profit before interest and tax })}{\text { Ordinary Share Capital }+ \text { Reserves }+ \text { Long-term borrowing }} \times 100 \%
$$

As shown in Table 1 and Figure 1, Tesco performance in relation to ROCE was improving because the ratios were above ideal percentage 10\% but the operating profit fell sharply in 2013 by 52\% though it has increased by 
Table 1. Return on capital employed of Tesco Plc from 2010 to 2014.

\begin{tabular}{cccccc}
\hline Year & 2014 & 2013 & 2012 & 2011 & 2010 \\
\hline Operat. Prof & 2631 & 2188 & 4182 & 3811 & 3457 \\
Share + Reser & 14,715 & 16,643 & 17,775 & 16,535 & 14,596 \\
Long Term B & 9188 & 9946 & 9777 & 9541 & 11,580 \\
ROCE & $\mathbf{1 1 . 0 0 \%}$ & $\mathbf{8 . 2 2 \%}$ & $\mathbf{1 5 . 1 7 \%}$ & $\mathbf{1 4 . 6 1 \%}$ & $\mathbf{1 3 . 2 1 \%}$ \\
\hline
\end{tabular}

Source: Tesco Plc financial reports in 2010, 2011, 2012, 2013 and 2014.

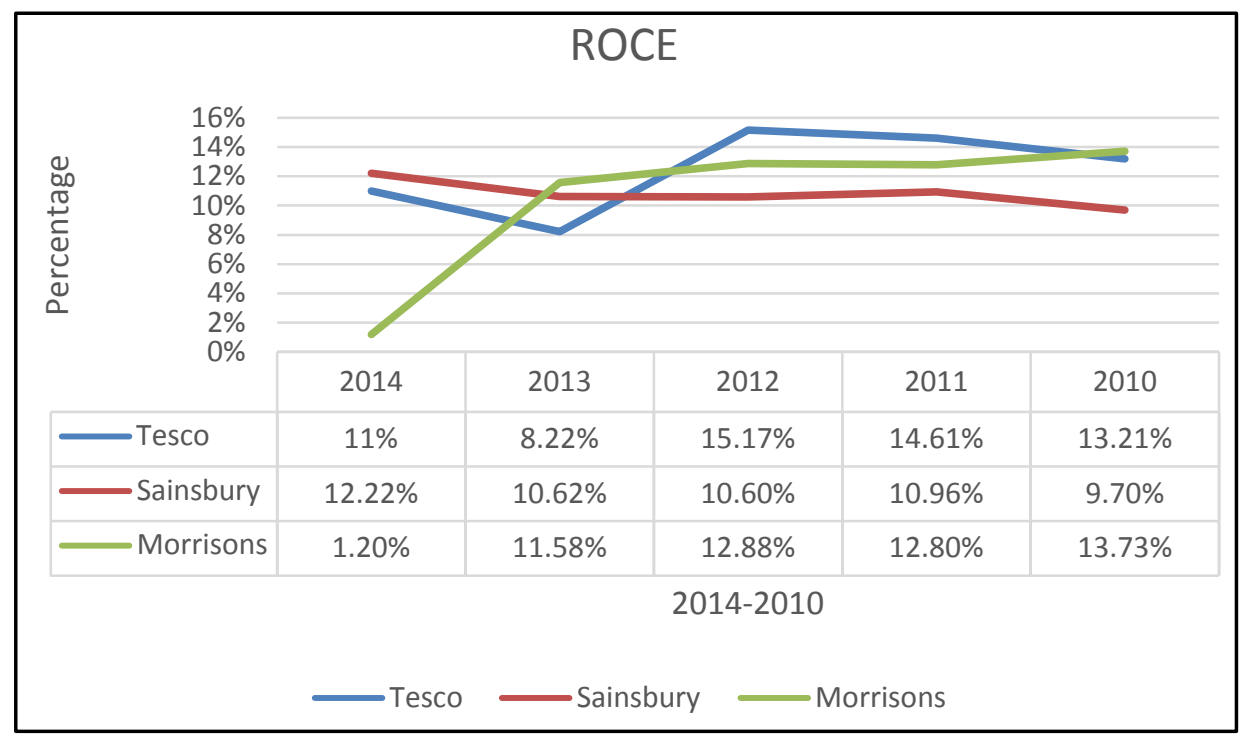

Figure 1. A chart to compare ROCE of Tesco Plc with Sainsbury and Morrissons.

$120 \%$ in 2014. The ROCE of Tesco is better than both Sainsbury and Morrisons.

2) Assets Turnover Ratio

Asset utilization ratio indicates how profitable a company is in relation to its assets. One of the ways to measure the efficiency of company's management is the way they convert assets available into profits. This ratio is considered an overall measure of profitability as it measures how much net income was generated for each $£ 1$ of assets the company has. It is simple Revenue/(Share Capital + Reserves + Long-Term Borrowings).

As shown in Table 2 and Figure 2, Tesco Plc’s Assets turnover is increasing but Sainsbury performed better than Tesco with regards to Assets Turnover in the period under review.

3) Net Profit percentage

This ratio expresses net profit of an organization as a percentage of turnovers. It is the profit margin after cost of sales and all relevant revenue expenses has been deducted. The higher the ratio is, the better for the business.

$$
\text { NET PROFIT\% }=\frac{\text { Net Profit }}{\text { Revenue }} \times 100 \%
$$

As shown in Table 3 and Figure 3, the average growth was 27.93\% during the periods under review as against negative growth of $1.37 \%$ in gross profit margin. This indicates that Tesco was able to minimize its expenses except in 2013 when the expenses were highly abnormal $£ 1901$ million i.e. (Gross profit £4089 m) less net profit $(£ 2188 \mathrm{~m})$ ). Tesco generated averagely more Net Profit than both two companies except in 2013.

\subsection{Efficiency Ratio}

These ratios analyze how well an organization makes use of its resources to generate revenue. It is made up of the following ratios:

1) Inventory days ratio 
Table 2. Assets utilisation of Tesco Plc from 2010 to 2014.

\begin{tabular}{cccc}
\hline Year & Revenue (a) & Ordinary Share + Reserves + Long Term Borrowings (b) & (a) $\div$ (b) \\
\hline 2010 & 56,910 & 26,176 & 2.17 \\
2011 & 60,931 & 26,076 & 2.33 \\
2012 & 64,539 & 27,552 & 2.34 \\
2013 & 64,826 & 26,589 & 2.44 \\
2014 & 63,557 & 23,903 & 2.66 \\
\hline
\end{tabular}

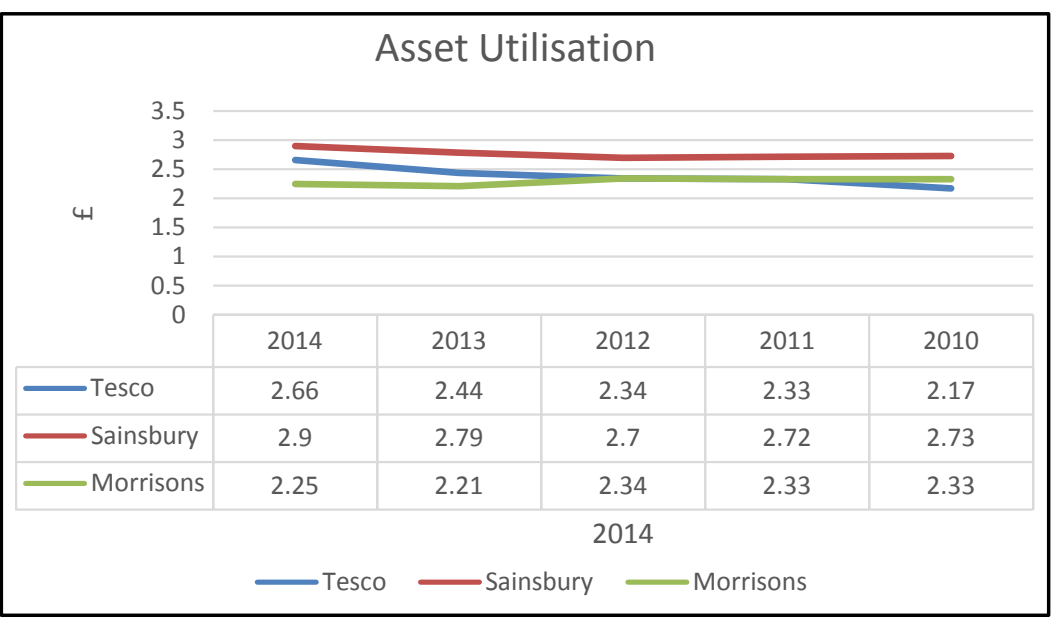

Figure 2. Asset utilisation of Tesco Plc compared with Sainsbury and Morrisons.

Table 3. Tesco Plc’s net profit \% from 2010 to 2014.

\begin{tabular}{cccc}
\hline Year & Net Profit \% & Annual growth & Average growth \\
\hline 2010 & $5.58 \%$ & & \\
2011 & $5.80 \%$ & $3.94 \%$ & $4.78 \%$ \\
2012 & $5.94 \%$ & $24.14 \%$ & $-41.16 \%$ \\
2013 & $3.02 \%$ & $17.55 \%$ & \\
2014 & $3.55 \%$ & & \\
\hline
\end{tabular}

Sources: Tesco Plc’s financial reports in 2010, 2011, 2012, 2013 \& 2014.

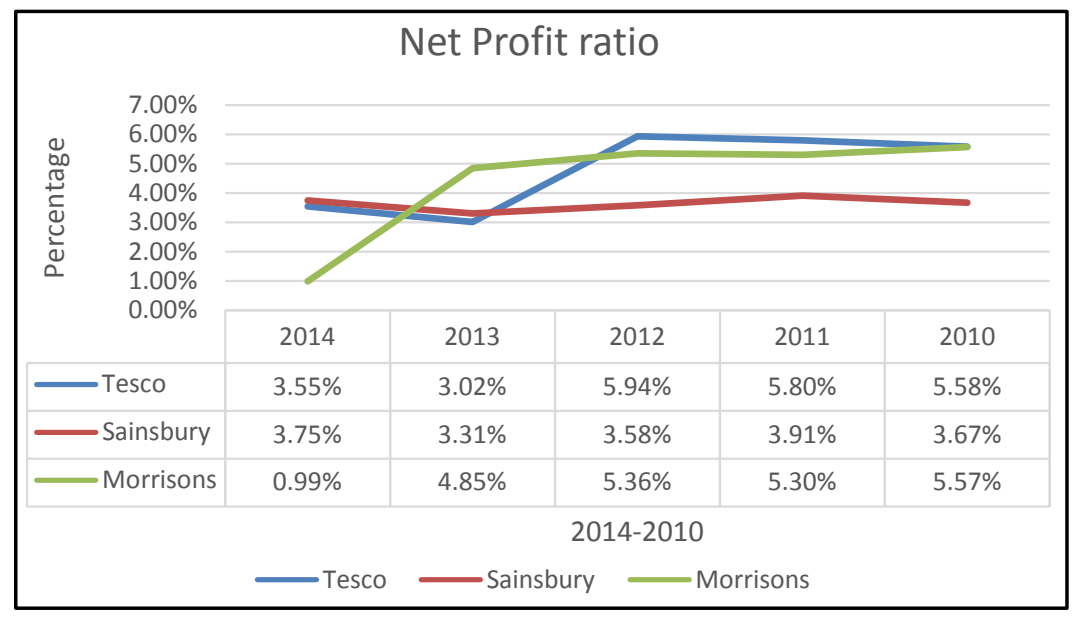

Figure 3. Net profit ratio. 
This ratio measures number of days stock are held in store before being sold. The lower the days are, the better for company's cost of sale is.

$$
\text { Inventory days ratio }=\frac{\text { Inventory }(\text { Stock Turnover })}{\text { Cost of Sales }} \times 365 \text { days }
$$

As shown in Table 4 and Figure 4, the Inventory (turnover) period of Tesco increased steadily from 2010 before it decreased in 2014 which is very good for the company. On average the stock inventory is 21.25 days, meaning that in a year Tesco Plc will be able to produce and sell their products ( $365 \div 21.25$ times), i.e. 17.18 times. This is a very good ratio especially for perishable items but in 2014, while Tesco will take 21.92 days to sell their products, Sainsbury and Morrison will only use 16.26 days and 18.73 days respectively. Tesco has to improve on this.

2) Debtors Turnover

Debtor Turnover measures number of day's trade creditors take to pay. The lower the days are, the better the trade creditors are.

$$
\text { Debtors Turnover }=\frac{\text { Trade Receivables }}{\text { Credit Sales }} \times 365 \text { days }
$$

As shown in Table 5 and Figure 5, Debtors Turnover of Tesco Plc has been decreasing as 2012 but on average, the Debtors Turnover ratio was 13.56 days. This needs to be compared with Creditors days for meaningful analysis. Tesco Plc's Debtors Turnover ratio was higher than other two because of high Turnover of Tesco.

3) Creditors days ratio

Creditor days ratio measures average days its takes a company to meet its obligation to trade creditors. The longer the days are, the better the credit purchase is.

Table 4. Tesco Plc’s inventory days ratio from 2010 to 2014.

\begin{tabular}{ccc}
\hline Year & Inventory days & Average days \\
\hline 2010 & 19.04 days & \\
2011 & 20.66 days & 21.25 days \\
2012 & 22.15 days & \\
2013 & 22.49 days \\
2014 & 21.92 days \\
\hline
\end{tabular}

Sources: Tesco Plc’s financial reports in 2010, 2011, 2012, 2013 \& 2014.

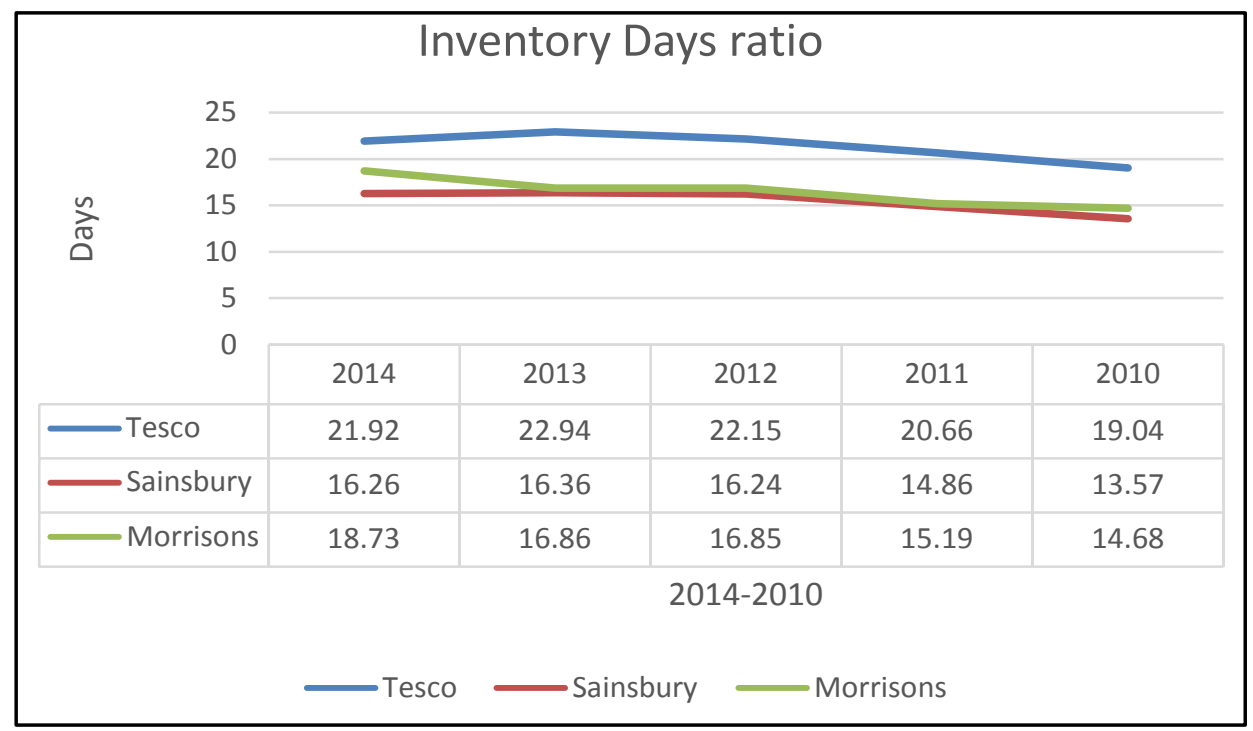

Figure 4. Inventory days ratio. 
Table 5. Tesco Plc’s debtors turnover from 2011 to 2014.

\begin{tabular}{ccc}
\hline Year & Debtors Turnover & Average days \\
2010 & 12.11 days & \\
2011 & 13.86 days & 13.56 days \\
2012 & 15.03 days & \\
2013 & 14.22 days \\
2014 & 12.58 days \\
\hline
\end{tabular}

Sources: Tesco Plc’s financial reports in 2010, 2011, 2012, 2013 \& 2014.

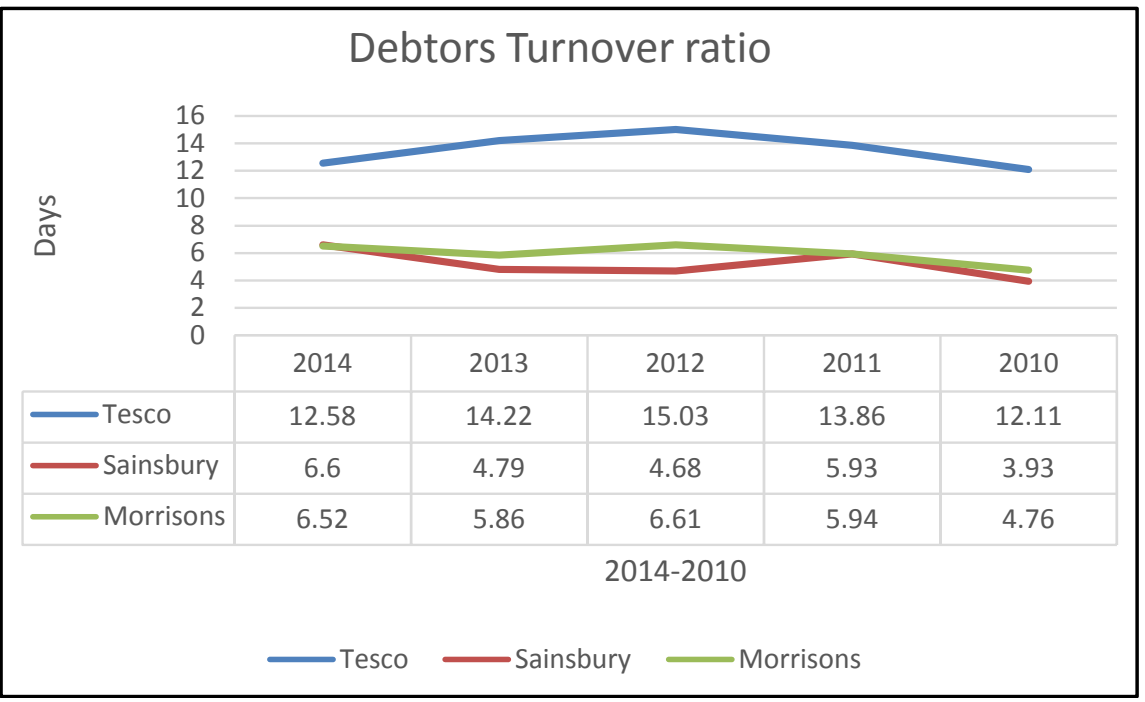

Figure 5. Debtors turnover ratio.

$$
\text { Creditors days }=\frac{\text { Trade Payables }}{\text { Credit Purchases }} \times 365 \text { days }
$$

As shown in Table 6 and Figure 6, on average Tesco's Creditor days was 67.03 days compared to Debtors turnover which was 13.56 days. This indicates efficient liquidity management on the part of Tesco Plc, with the result that the company will be able to use the credit facilities obtained from creditors to run the business as their debtors paid 53.47 days earlier before Tesco Plc paid their creditors.

\subsection{Financial Ratios}

1) Gearing Ratio

This is the ratio of long-term debt (debentures and preference shares) to total capital, a company with more than $50 \%$ gearing ratio is considered to be highly geared.

$$
\text { Gearing ratio }=\frac{\text { Long }- \text { term loan }}{\text { Long Term }+ \text { Share Capital }+ \text { Reserves }} \times 100 \%
$$

As shown in Table 7 and Figure 7, Tesco Plc's gearing ratio is high (though it is still on average within the ideal range of 50\%) when compared to Sainsbury and Morrisons.

2) Interest cover

This ratio measures how many times interest could be paid from operating profit of business, i.e. how well a company caters for interest on long term loans.

$$
\text { Interest cover }=\frac{\text { Profit before interest and tax }}{\text { Finance costs }}
$$


Table 6. Tesco Plc’s creditor days 2010-2014.

\begin{tabular}{ccc}
\hline Year & Creditor days & Average days \\
2010 & 65.89 days & \\
2011 & 68.49 days & 67.03 days \\
2012 & 69.17 days & \\
2013 & 66.67 days & \\
2014 & 64.94 days & \\
\hline
\end{tabular}

Sources: Tesco Plc’s financial reports in 2010, 2011, 2012, 2013 \& 2014.

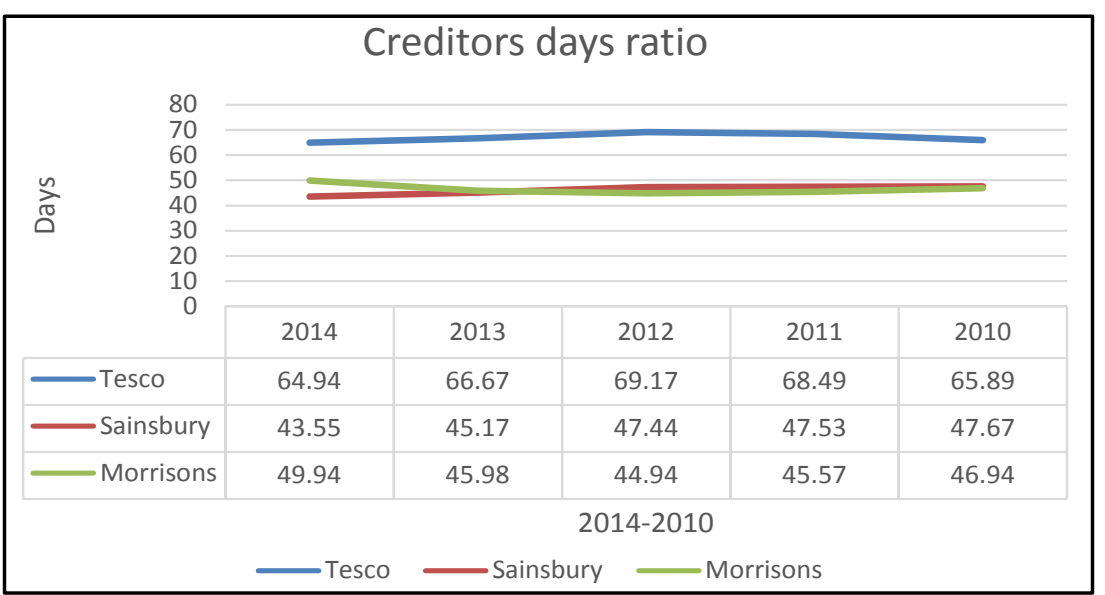

Figure 6. Creditors days ratio.

Table 7. Calculation of gearing ratios of Tesco Plc 2010 to 2014.

\begin{tabular}{ccccc}
\hline Year & Long-Term Loans (a) & Ordinary Share + Reserves (b) & (a) $+(\mathrm{b})$ & $(\mathrm{a}) \div(\mathrm{a}+\mathrm{b}) \times 100 \%$ \\
\hline 2010 & 11,580 & 14,596 & 26,176 & $44.24 \%$ \\
2011 & 9541 & 16,535 & 26,076 & $36.59 \%$ \\
2012 & 9777 & 17,775 & 27,552 & $35.49 \%$ \\
2013 & 9946 & 16,643 & 26,589 & $59.76 \%$ \\
2014 & 9188 & 14,715 & 23,903 & $38.43 \%$ \\
\hline
\end{tabular}

Sources: Tesco Plc’s financial reports in 2011, 2012, 2013 \& 2014.

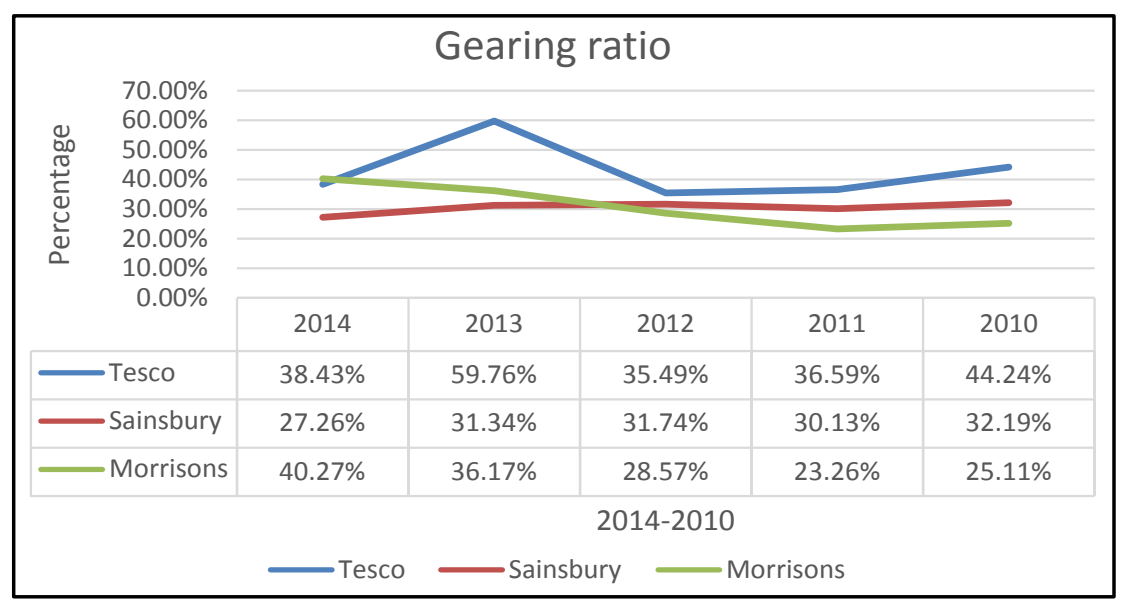

Figure 7. Gearing ratio. 
As shown in Table 8 and Figure 8, Tesco interest cover is adequate and the company can pay their interest payable 6.7 times on average. The higher the ratio the better for the company, three times is ideal ratio, a lower figure is an indicator of poor liquidity management and a sign of business failure.

\subsection{Liquidity Ratios}

Imply the ability of a company to meet its short-term debts before the due date and equally meet unexpected cash needs. A company with good liquidity can obtain funds easily as compared to its counterparts having lower liquidity. Companies compare liquidity on yearly basis and with those of competitors so as to make decisions [1].

The International Accounting Standards (IFRS, 2006) indicate the fact that liquidity refers to the available cash for the near future, after taking into account the financial obligations corresponding to that period. It is noteworthy that liquidity risk consists in the probability that the organization should not be able to make its payments to creditors, as a result of the changes in the proportion of long term credits and short term credits and the non-correlation of this with the structure of organization's liabilities.

These include but not limited to the following ratios:

1) Current Ratio

This ratio measures the ability of Tesco to pay its current obligations using current assets. It is a simple measure that estimates whether the business can pay debts that fall due within one year from the assets of the company. If the ratio is less than one, it will be a cause for concern, especially if it persists for long period of time. Ideal current ratio is 2:1. The higher the ratio is, the better the current assets are.

$$
\text { Current ratio }=\frac{\text { Current Assets }}{\text { Current Liabilities }}
$$

Table 8. Tesco Plc’s interest cover in 2010-2014.

\begin{tabular}{ccc}
\hline Year & Interest cover & Average \\
2010 & 5.99 times \\
2011 & 7.89 times \\
2012 & 10.18 times \\
2013 & 4.77 times \\
2014 & 4.66 times \\
\hline
\end{tabular}

Sources: Tesco Plc’s financial reports in 2010, 2011, 2012, 2013 \& 2014.

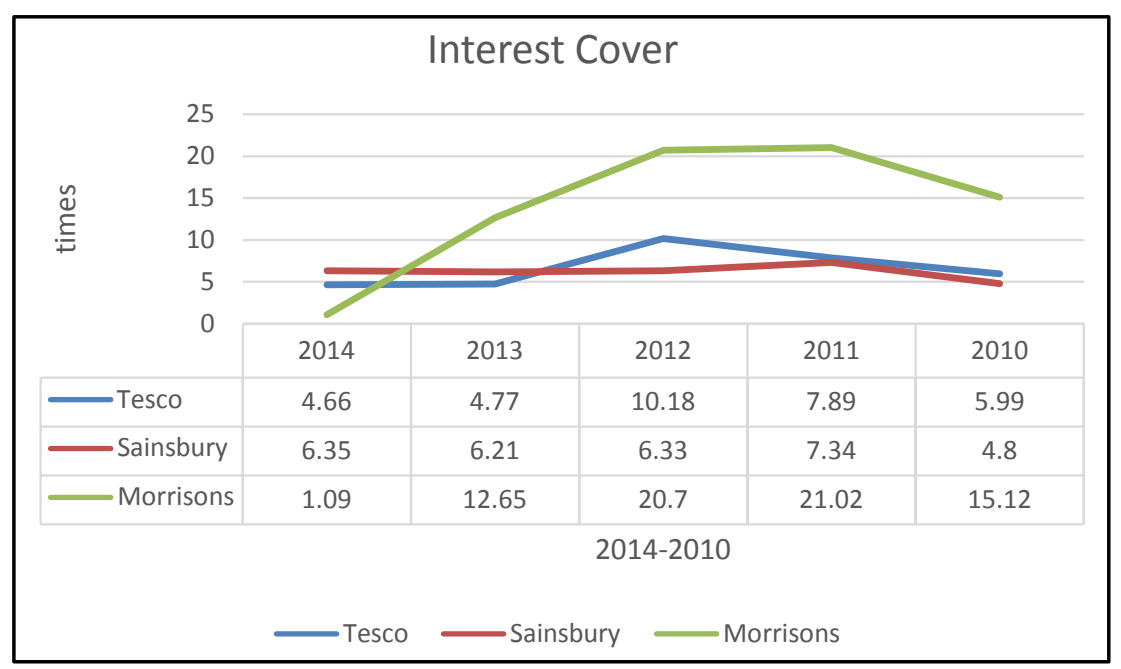

Figure 8. Interest cover. 
As shown in Table 9 and Figure 9, these ratios show that Tesco Plc is over trading because the ratios are less than 1:1 from 2010 to 2014. Ideal current ratio is $2: 1$ although 1.5:1 is more realistic, lower figures is a sign of poor liquidity management meaning that on average Tesco can only pay $70 \%$ of her short-term liabilities. Tesco actually is better than both Sainsbury and Morrisons in this aspect.

2) Acid-Test Ratio

This is often referred to as the quick ratio. Quick assets are defined as cash, marketable (or short-term) securities, and accounts receivable and notes receivable, minus the allowances for doubtful accounts. These assets are considered to be very liquid which means they can easily be converted to cash and therefore, useful for immediate use to pay obligations. Quick ratio is calculated as the current assets less inventory and divided by the current liabilities. The ideal ratio is $1: 1$ which means that company is able to pay all its current liabilities from its quick current assets (1).

$$
\text { Quick ratio }=\frac{\text { Current Assets less Inventory }}{\text { Current Liabilities }}
$$

As shown in Table 10 and Figure 10, Tesco's Quick Ratios were below the ideal standard which is ratio 1:1 or at worst $0.7: 1$. This also point to the fact that there is poor liquidity management in Tesco Plc over the years.

\subsection{Shareholders and Investors' Interests Ratios}

1) Price/Earnings ratio.

This ratio is a key ratio for the investors who may need to know how well their shares are likely to perform and it is calculated by dividing Market share price by Earnings per share.

As shown in Table 11 and Figure 11, the basic and diluted Price/Earnings ratios are not consistent.

Table 9. Tesco Plc’s current ratios in 2010-2014.

\begin{tabular}{ccc} 
Year & Current Ratio & Average \\
\hline 2010 & $0.73: 1$ & \\
2011 & $0.67: 1$ & $0.70: 1$ \\
2012 & $0.67: 1$ & \\
2013 & $0.69: 1$ & \\
2014 & $0.73: 1$ & \\
\hline
\end{tabular}

Sources: Tesco Plc's financial reports in 2010, 2011, 2012, 2013 \& 2014.

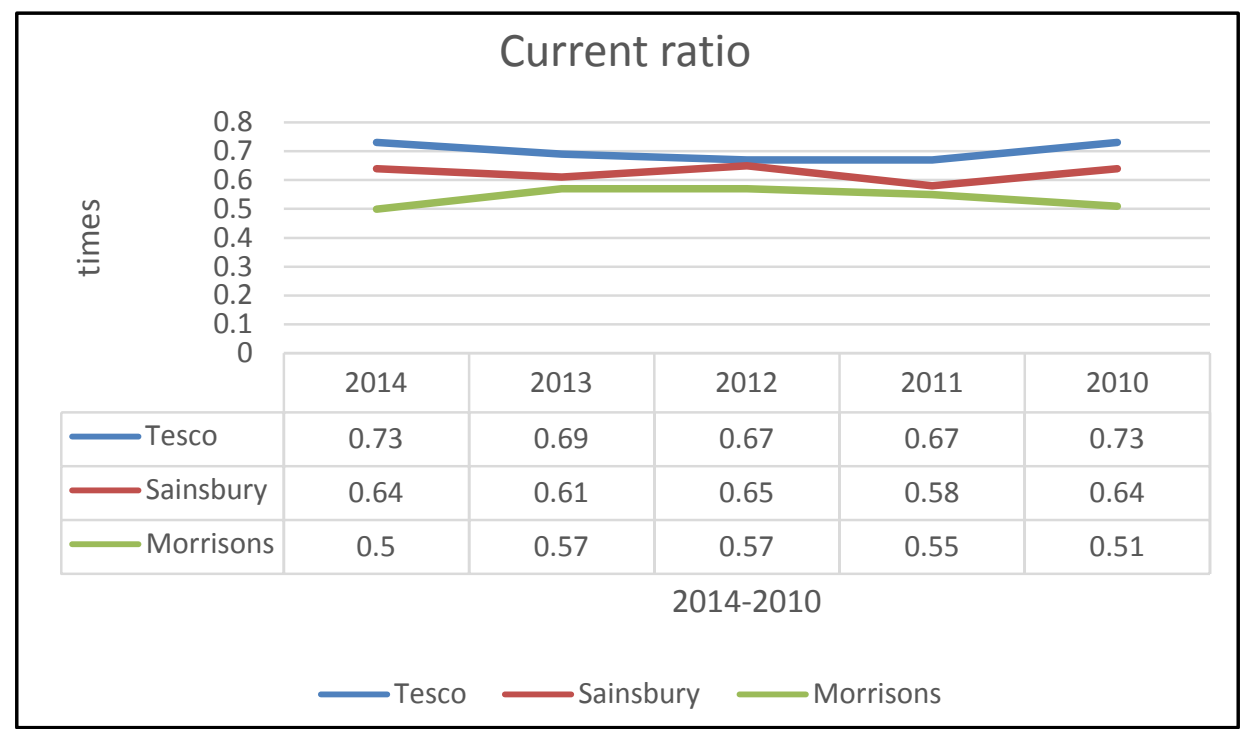

Figure 9. Current ratio. 
Table 10. Tesco Plc’s quick ratios in 2010-2014.

\begin{tabular}{ccc}
\hline Year & Quick Ratio & Average \\
\hline 2010 & $0.56: 1$ & \\
2011 & $0.49: 1$ & $0.60: 1$ \\
2012 & $0.48: 1$ & \\
2013 & $0.89: 1$ & \\
2014 & $0.56: 1$ & \\
\hline
\end{tabular}

Sources: Tesco plc’s financial reports in 2010, 2011, 2012, 2013 \& 2014.

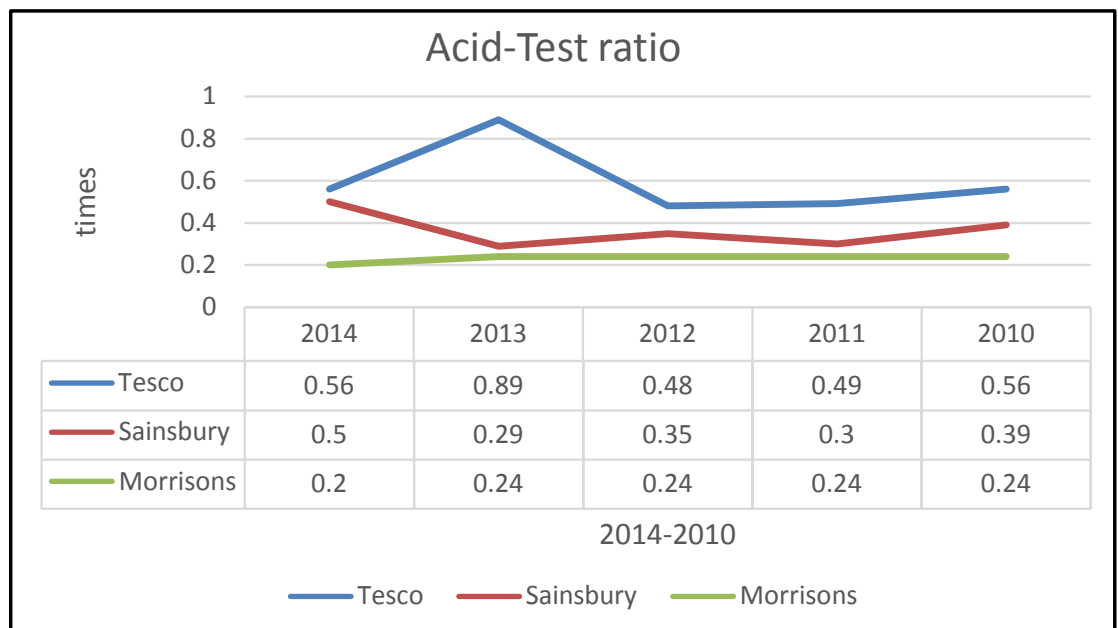

Figure 10. Acid-test ratio.

Table 11. Price/earnings ratio of Tesco Plc from 2010 to 2014.

\begin{tabular}{|c|c|c|c|c|c|}
\hline Year & Market Share Price & EPS (basic) & EPS (diluted) & P/E Ratio (Basic) & P/E Ratio (Diluted) \\
\hline 2010 & 419.70p & 29.33p & 29.19p & 14.31 times & 14.38 times \\
\hline 2011 & $402.20 p$ & 33.10p & $32.94 p$ & 12.15 times & 12.21 times \\
\hline 2012 & $316.10 p$ & $39.35 p$ & $39.23 p$ & 8.03 times & 8.06 times \\
\hline 2013 & $369.60 p$ & $17.30 \mathrm{p}$ & 17.30p & 21.36 times & 21.36 times \\
\hline 2014 & $329.20 p$ & $23.75 p$ & 23.72p & 13.86 times & 13.88 times \\
\hline
\end{tabular}

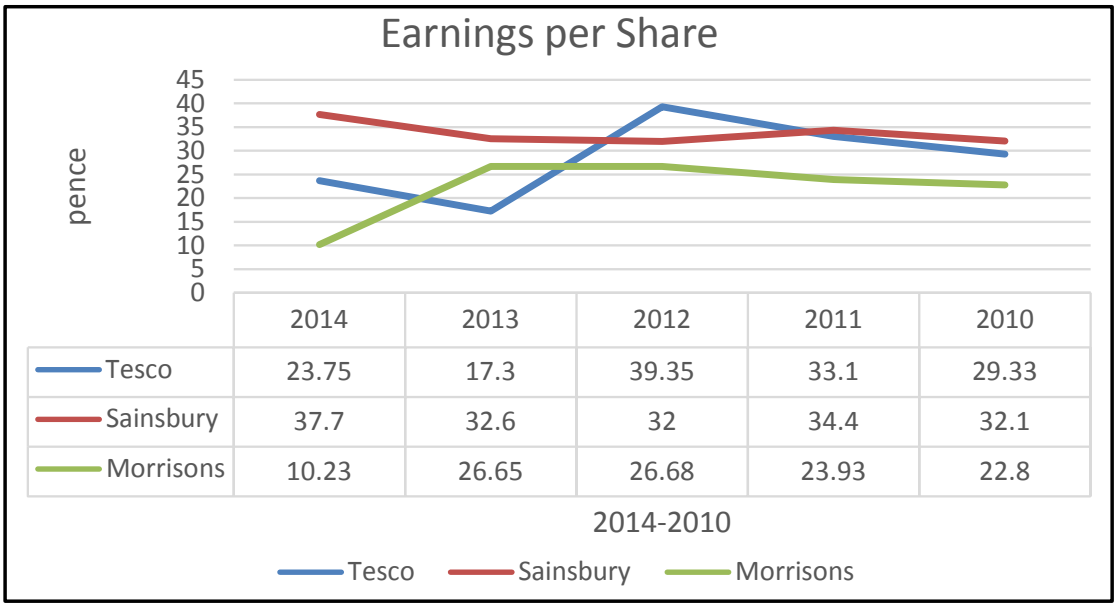

Figure 11. Earnings per share. 
2) Return on Equity (Investment)

The ratio is focus on the return for shareholders. It is computed as profit after tax and preference shares dividend divided by ordinary shares capital and reserves.

$$
\text { Return on Equity }=\frac{\text { Profit after tax less preference dividend }}{\text { Ordinary shares plus Reserves }} \times 100 \%
$$

Table 12 indicates that ROI moves in the same direction with profit after tax.

Table 13 shows that there was a consistent increase in the amount of dividends paid as at the year 2010 but the percentage of payment dwindled seriously in 2013 and 2014 unlike the first two previous years.

It could be seen from Table 14, as the share prices were reducing from 2010, the Dividend yields were equally reducing.

Dividend Yield: Dividend yield indicates the amount an investor may receive in return for buying a share with Tesco Plc.

As shown in Table 15, the average growth rate of the Tesco dividend yield is not good except in 2013.

3) Dividend Cover

This ratio implies the safety of a company's dividend payment and it is calculated by dividing Earnings per share with Dividend per share.

As shown in Table 16 and Figure 12, a dividend cover of at least 2 indicates good management practice but Tesco Plc only has more than 2 in 2012, indicating Tesco Plc has very low capacity to increase dividend payments in the future unlike Morrisons.

Table 12. Tesco’s return on equity 2011-2014.

\begin{tabular}{cccc}
\hline Year & Return on Equity & Annual growth & Average growth \\
2011 & $21.38 \%$ & & \\
2012 & $21.58 \%$ & $0.94 \%$ & $-4.72 \%$ \\
2013 & $11.78 \%$ & $-45.41 \%$ & \\
2014 & $15.35 \%$ & $30.31 \%$ & \\
\hline
\end{tabular}

Source: Tesco Plc’s financial reports in 2010, 2011, 2012, 2013 \& 2014.

Table 13. Dividend growth of Tesco Plc from 2010 to 2014.

\begin{tabular}{cccc}
\hline Years & Dividend paid (£’Million) & Growth & Average growth rate \\
\hline 2010 & 968 & & \\
2011 & 1081 & $9.16 \%$ & $5.40 \%$ \\
2012 & 1180 & $0.34 \%$ & \\
2013 & 1184 & $0.42 \%$ & \\
2014 & 1189 &
\end{tabular}

Sources: Tesco Plc’s financial reports in 2010, 2011, 2012, 2013 \& 2014.

Table 14. Share price, growth and average growth of Tesco Plc from 2010 to 2014.

\begin{tabular}{cccc}
\hline Date & Share Price & Growth & Average growth rate \\
\hline $28 / 02 / 2010$ & $419.70 \mathrm{p}$ & \\
$28 / 02 / 2011$ & $402.20 \mathrm{p}$ & $-41.70 \%$ & $-21.41 \%$ \\
$29 / 02 / 2012$ & $316.10 \mathrm{p}$ & $16.93 \%$ & $-14.28 \%$ \\
$28 / 02 / 2013$ & $369.60 \mathrm{p}$ & $-10.93 \%$ & \\
$28 / 02 / 2014$ & $329.20 \mathrm{p}$ & & \\
\hline
\end{tabular}

Source: Tesco Plc’s financial reports in 2010, 2011, 2012, 2013 \& 2014. 
Table 15. Share price, growth and average growth of Tesco Plc from 2010 to 2014.

\begin{tabular}{cc}
\hline Year & Dividend Yield \\
\hline 2010 & 20.99 \\
2011 & 20.11 \\
2012 & 15.81 \\
2013 & 18.50 \\
2014 & 16.46 \\
\hline
\end{tabular}

Table 16. Dividend yield of Tesco Plc from 2010 to 2014.

\begin{tabular}{|c|c|c|c|}
\hline Years & Dividend Cover & Growth & Average growth rate \\
\hline 2010 & 1.40 & & \\
\hline 2011 & 1.65 & $17.86 \%$ & \\
\hline 2012 & 2.48 & $50.30 \%$ & $11.87 \%$ \\
\hline 2013 & 0.94 & $-62 \%$ & \\
\hline 2014 & 1.44 & $53.19 \%$ & \\
\hline
\end{tabular}

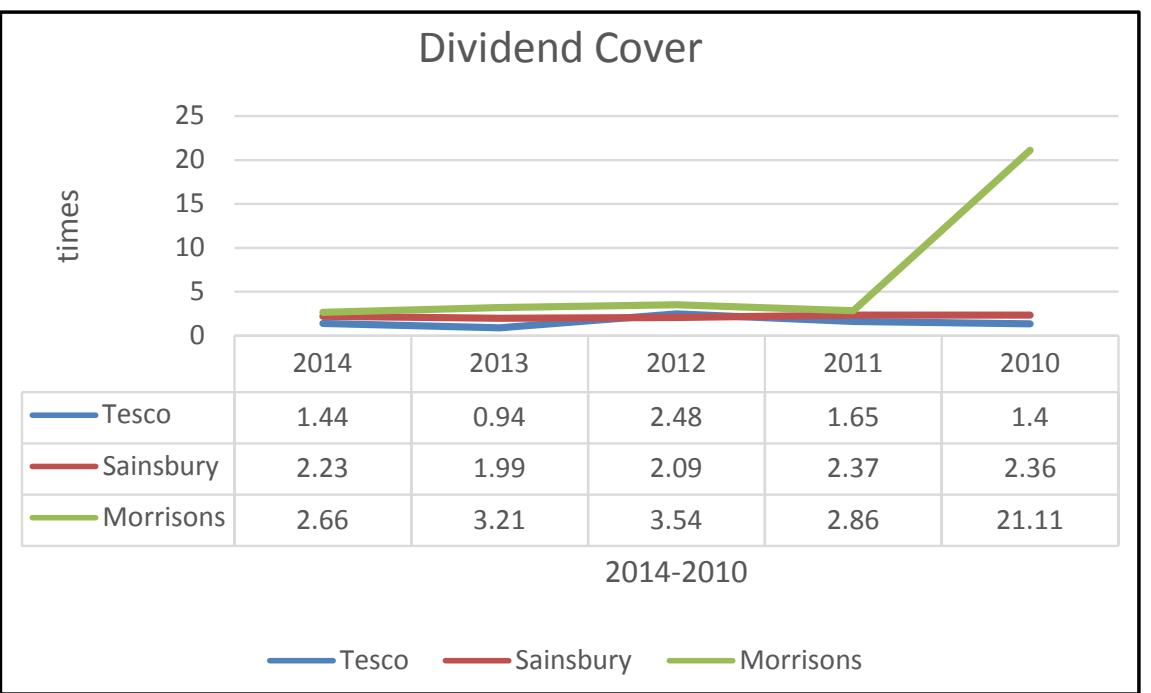

Figure 12. Dividend cover.

\section{Conclusion and Recommendations}

In summary, with the analyses of the ratios on Tesco Plc, it may be concluded that the performance between 2010 and 2014 was not satisfactory when compared to other companies in the same industry like Sainsbury and Morrisons. Though Tesco's online shopping is slowly growing, it still accounts for a small percentage of total revenue especially in international market [2]. In fact, Tesco Plc has a strong potentiality and growth in online shopping across the UK and China. Therefore, in the future, Tesco should ensure to improve the operations' capability of online grocery shopping and prepare for online retailing's international expansion.

\section{References}

[1] Lundholm, R. and Sloan, R. (2012) Equity Valuation and Analysis w/eVal. McGraw Hill/Irwin, New York.

[2] Moving Online (2012) Business Europe, 1, 8. 


\section{Submit or recommend next manuscript to SCIRP and we will provide best service for you:}

Accepting pre-submission inquiries through Email, Facebook, LinkedIn, Twitter, etc.

A wide selection of journals (inclusive of 9 subjects, more than 200 journals)

Providing 24-hour high-quality service

User-friendly online submission system

Fair and swift peer-review system

Efficient typesetting and proofreading procedure

Display of the result of downloads and visits, as well as the number of cited articles

Maximum dissemination of your research work

Submit your manuscript at: http://papersubmission.scirp.org/ 